\title{
Cihat Burak'ın Resimlerinde Türk Bayrağı İmgesi
}

\author{
Öğr. Gör. Serkan Çalışan
}

Makale Geliş Tarihi: 08.03.2016

Yayına Kabul Tarihi: 23.05.2016

\section{Öz}

Bu araştırma, Türk resim sanatında özgün duruşu ve resimlerindeki farklı tavrıyla dikkat çeken Cihat Burak'in resimlerindeki bayrak imgesinin izini sürmeyi hedeflemektedir. Avrupa'da ulus devlet rejimlerine geçişle birlikte bayraklar, milli marşlar gibi ulusun tarihsel geçmişini övgüyle anan kutsallaştırılmış nesnelere dönüşmüştür. Gerek Batı resim sanatında gerekse Türk resim sanatında, içeriğinde bayrak imgesi bulunan çalışmalara sıklıkla rastlanmaktadır. Cihat Burak'in çalışmalarındaki plastik dil ve buna bağı olarak kavramsal alt metinleri bayrak bağlamıyla nasıl bir ilişki kurduğu, çă̆daşları veya ondan önceki kuşakların bayrak imgesini resim düzleminde nasıl incelediği tartışmanın ana eksenini oluşturacaktır. Bu da, gerek resim karşılaştırmaları gerekse sanatçı hakkında yazılan metinler aracılığı ile açıklanmaya çalışılacaktır.

Anahtar Kelimeler: Cihat Burak, Bayrak, Resim

\section{IMAGE OF TURKISH FLAG IN CIHAT BURAK'S PAINTINGS}

\section{Abstract}

This research aims to track the flag image in the pictures of Cihat Burak who draws attention with his distinctive stance and different attitude in pictures in Turkish painting art. Along with transition to the nation-state regimes in Europe, flags turned into sacralized objects that praise the historical background of the nation such as national anthems. Studies containing the flag image are frequently encountered both in Western painting art and Turkish painting art. How Cihat Burak associated the plastic language and accordingly conceptual sub-texts in his studies to the context of flag and how contemporaries or predecessors examined the flag image on the picture plane will constitute the main axis of the discussion. An attempt to explain this will be made through picture comparisons and texts written about the artist.

Keywords: Cihat Burak, Flag, Painting

Öğr. Gör. Serkan Çalışkan, Kırklareli Üniversitesi, Lüleburgaz Meslek Yüksekokulu, 


\section{Cihat Burak'ın Resimlerinde Türk Bayrağı İmgesi}

Aidiyet, temsil, vatan, kutsalık gibi çoğaltılabilecek birçok anlama sahip simgesel bir nesne olan bayraklar, çoğunlukla fabrikalarda çeşitli renkleri ve şekilleri içeren kumaşlardan üretilmektedir. Sıradan bir nesne olan bayraklar, tek başlarına bir anlam ifade etmemektedir. Bu açıdan bakıldığında da Roland Barthes'ın nesneler için yaptığı tanım, nesne bayraklar için de geçerli sayılabilir. Yazara göre: "Görülmeyi bekleyen şeydir, düşünen özneye göre düşünülen şeydir, kısacası, çoğu sözcüğün verdiği biçimiyle, nesne herhangi bir şeydir; nesne sözcüğünün yan anlamlarının neler olduğunu anlamaya çalışmadıkça, bize hiçbir şey vermeyen bir tanımdır bu" (Barthes, 2012: 195). Ancak, özellikle ulus devlet rejimlerine geçişle birlikte bayrağın nesne olarak ontolojik yapısı da değişime uğrar. "Bayrağın, kendi başına hiçbir değeri olmayan, yalnızca temsil ettiği gerçekliği akla getiren sembol olduğunu unutur. Bayrağa, temsil ettiği şeyin bizatihi kendisi imiş gibi davranır" (Durkheim, 2011: 302). Bu açıdan bakıldığında da ulus devletler için bayrak olgusu, milli marşlar gibi çoğaltılabilecek olgularla birlikte ulusların kutsallaştırılmaya çalıştıkları tarihin bir parçası olmaktadır. Bayrağa saygı kavramı da yasalarla koruma altına alınan nesneyi tabu nesnesine dönüştürürken, Barthes'ın da değindiği yan anlamlardan yararlanılmaktadır.

Etimolojik olarak bayrak, Uygurca'daki "badruk"1 kelimesine dayanmaktadır. "Kaşgarlı Mahmut'tan bu kelimenin 11. yüzyılda Bayrak ve Batrak biçimlerinde ve aşağı yukarı bugünkü anlamda kullanıldığını öğrenebiliyoruz" (Kurtoğlu, 1987: 3). Türk bayrağının tarihsel dönüşümlerine bakıldığında da farklı imgeler ve renklerle karşılaşılmaktadır. Orta Asya Türkleri'nde askeri amaçlarda ve törensel durumlarda kullanılan bayraklar, mavi, kırmızı ve beyaz gibi çeşitli renklere sahiptir. Bunun yanında bayrakların kullanımı için bazı şartlar bulunmaktadır. "Devlet, ikbal ve rütbe sahibi. Bu bayrağa sahip olan kişi veya halk kağan veya kağanlık olabilir, komutan olabilir; ancak onu elinde tuttukça saygı gösterilebilir" (Ögel, 1984: 9). Osmanlı İmparatorluğu'nda ise hemen hemen her padişahın kendine ait bir sancağı bulunmaktadır. Bu bayrakların renkleri çeşitlilik gösterdiği gibi üzerlerinde bulunan sembollerde de farklılıklar vardır. Çoğunlukla İslamiyet etkisi görülmektedir ve bazılarının üzerlerinde Kur'an'dan ayetler bulunmaktadır. Günümüzde Türkiye Cumhuriyeti'nin kullandığı kırmızı zemin üzerine ay-yıldız imgesinin tarihi ise 1848'e dayanmaktadır. Cumhuriyet'in ilanıyla birlikte resmi bayrak olarak kullanılıyor olsa da, T.C. İçişleri Bakanlığı'nın 22/09/1983 yılında 2893

'http://www.etimolojiturkce.com/kelime/bayrak 
kanun sayısı ile yasalaştırılmıştır. Buna göre, bayrakta kullanılacak renk, ay-yıldızın ölçüleri yasa kapsamında belirtilmiştir.

Bu açıklamalar bağlamında resim sanatına bakıldığında da, gerek Batı resim sanatında gerekse Türk resim sanatında sıklıkla kullanılan bir imge olarak, sembolik nesnenin taşıdığı anlamlarla birlikte karşımıza çıkmaktadır. Bayrak imgesinin resim sanatında plastik bir öge olarak kullanılmasının yanı sıra, resmin kavramsal alt metinini oluşturan bir öge olarak da kullanıldığı görülmektedir.

Türk resim sanatının Tanzimat ile başlayan batııılaşma serüveni, Cumhuriyet dönemi ile daha da belirgin bir kimlik yapısına dönüşmüştür. Nilüfer Öndin'e göre:

Cumhuriyet'in kuruluş yıllarından itibaren sanat, yalnızca estetik bir sorun olmamıs, çağdaşlaşmayı sağlayacak devrimlerin, halka benimsetilmesi işlevini de sürdürmüştür. Bu bağlamda sanata önem verilmesi okuma-yazma oranının düşük olduğu ülkede, göz ve kulağa hitap eden sanatın, bireyi daha kolay etkileyeceği gerçekliğinden kaynaklanır. Sanat, eğitim işlevini de dolaylı olarak yüklendiğinden, devrimlerin benimsetilmesinde bir propaganda aracı olur (Öndin, 2003: 203).

$\mathrm{Bu}$ süreçte resmin plastik yapısına dair arayışlar kadar, dönemin sosyoekonomik yapısı ve hâkim ideolojinin etkileri plastik sanatlar alanında üretilen çalışmalara da yansımaktadır. Dönemin çalışmalarına bakıldığında, ideoloji ve sanat arasındaki ilişkinin taşıyıcı lokomotifinin genellikle bayrak imgesi olduğu görülmektedir. Bu etki, İnkılap Sergileri ve Yurt Gezileri gibi tek parti dönemine ait etkinliklerde daha net bir şekilde görülmektedir. Örnek vermek gerekirse, Zeki Faik İzer "İnkılap Yolunda" (I. İnkılap Sergisi), Arif Kaptan "Cumhuriyetin Gençliğe Tevdii" (II. Inkılap Sergisi), Abidin Elderoğlu "Ayrılış" (III. İnkılap Sergisi) eserleri ele aldığında, içerisinde bayrak imgesinin baskın bir şekilde görülmesi açısından, sanat ve ideoloji arasındaki ilişkiyi göstermek adına uygun olacaktır. Daha sonraki dönemlerde bayrak imgesinin ideolojiden bağımsız da plastik sanatlarda yer bulduğu görülmektedir. Diğer bir deyişle:

Eserler yalnızca yeni kurulan devlete ve yeni rejime yönelik övgü bağlamından uzaklaşan gösterge olarak da kullanılmaktadır. Hatta 1980 sonrası süreçte bayrağın yapı-söküme uğratıldığı çalışmalarda artış gözlemlenmektedir. Bu çalışmalarda plastik sunum bakımından dönüşümlerin yanı sıra, bayrak kavramının ulus devlet ideolojisi ve buna bağlı olarak kimlik politikaları bağlamında sorgulandığı ve sanatsal olarak tartışmaya açıldığı görülmektedir (Çalışkan, 2016: 1-4).

Cihat Burak'ın (1915-1994) resimlerindeki bayrak imgesine bakıldığında, 
Burak'ın Türk resim sanatında farklı bir noktada durduğu söylenebilir. Mimarlık eğitimi sonrasında resim çalışmalarına yoğunlaşan Cihat Burak, resim dışında seramik ve edebiyat gibi farklı disiplinlerde de çalışmalar üreten çok yönlü bir sanatçıdır. Her ne kadar üslup olarak belli kalıplara uymasa $\mathrm{da}$, sanatçının eserleri fantastik resim ve/veya Yeni Figürasyon akımlarına yakınlık göstermektedir. Dönemine ve sonraki dönemlere dair ayrıksı ifadesi; resimlerindekinesnelerin, figürlerin, hayvanların, renklerin izleyiciye aktardığı düşünsel alan, mizah ve absürtlük arasında şaşırtmacalıdır. Cihat Burak'ın çalışmalarında bayrak imgesinin izi sürüldüğünde ise sanatçının ayrıksı ifadesi burada da göze çarpmaktadır. Şöyle ki, içeriğinde bayrak olan diğer çalışmaların aksine, Cihat Burak'ın çalışmalarında ideolojiye övgü ya da yerme amacı doğrudan doğruya birinci elden aktarılmaz. Sanatçı, resimlerinde aktarmak istediği olayın, durumun ya da duygunun altını çizmektedir. Bununla birlikte, Cihat Burak'ın çalışmalarında bayrak imgesi, sanatçının gözlem yeteneğinin parçası olarak bir belge niteliği de taşımaktadır. Burak'ın resimlerinde bayrak imgesinin içeriliklerine bakılacak olursa; Milli Mücadele, tören, aile, gündelik hayatın içindeki halktan kişiler, toplumsal olaylar ve tarihsel konular olarak sınıflandırılabilir.

Cihat Burak'ın "Karafatma" (1968) adlı eseri içeriğinde Türk bayrağı imgesi bulunan belge nitelikli çalışmalarından biridir. Çalışmada bulunan bayrak imgesi, Milli Mücadele yıllarında kadınların rolüne göndermeler barındırdığı söylenebilir.

İstanbul Modern kapsamında yapılan retrospektife ait katalogda Karafatma İngilizceye "Cockroach" olarak çevrilmiş olsa da, "Karafatma" bir böceğe gönderme değildir. Türkiye'ye ait bir lakaptır. İzmir'de Kurtuluş Savaşı'na asker olarak katılan Fatma Seher Erden'in, Atatürk tarafından Kara Fatma olarak çağrıldığı bilinmektedir. Yapılan araştırmalarda Fatma Seher Erden'e ait fotoğraflarla Cihat Burak'ın eserindeki figür karşılaştııılı̆̆ında, benzerlik çok açıktır. Bu lakap sayesinde figür anonim olmaktan çıkmış, doğrudan bir kişiye işaret etmektedir (Çalışkan, 2016: 101).

Benzer konuyu içeren ve yukarıda da İnkılap Sergileri kapsamında adı geçen Zeki Faik İzer, Arif Bedii Kaptan, Abidin Elderoğlu gibi sanatçıların aksine Burak'ın çalışmasında, Kurtuluş Savaşı'nın destansı anlatılarında olmayan bir şey vardır. Bir kadın figürünün kahramanlığına gönderme bulunmaktadır. Cephelere silah taşıyan, askerlere yardım eden kadın anlatııının dışında, cephede silahlı mücadelede yer almış üniformalı bir figürdür Fatma Seher Erden. Diğer bir deyişle, Cumhuriyet ideolojisi yüceltirken destansı anlatımdan çok gerçek bir kahraman sanatçının konusu olmuştur. Cihat Burak Mustafa Kemal Atatürk'e hayranlığını Yahşi Baraz ile yaptığı ankette 
açıkça dile getirmektedir. "Yahşi Baraz: En sevdiğiniz tarihi kişilikler? Cihat Burak: Atatürk" (Çalıkoğlu, 2008: 284). Cihat Burak'a ait başka resimlerden de görebileceğimiz üzere, sanatçının gazete fotoğraflarından yararlanarak popüler kültür figürlerine ait görsellerden yararlandığı bilinmektedir. "Kara Fatma" eseri de muhtemelen o sıralarda gazetelerde yayınlanan Fatma Seher Erden'in fotoğraflarından yola çıkılarak üretilmiştir.
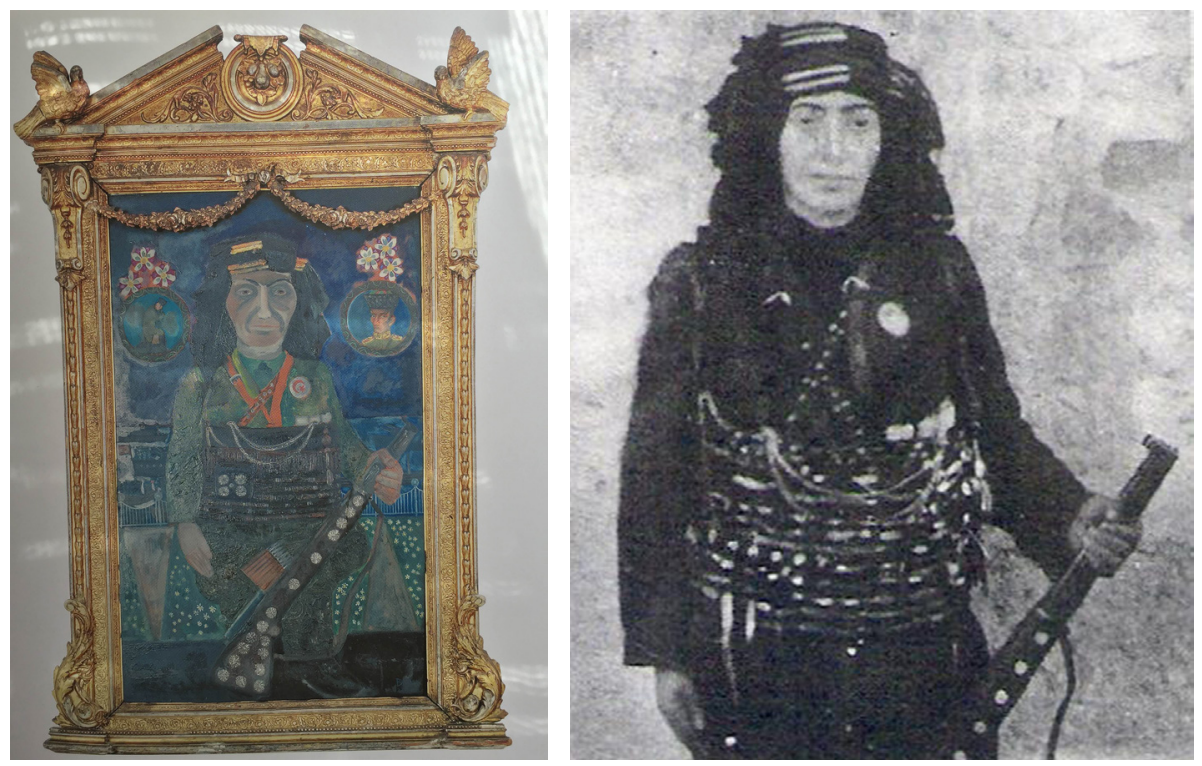

Resim I. Cihat Burak, Kara Fatma, 1968, Tuval Üzerine Yağlı Boya, I20x73 cm.

Resim 2. Fatma Seher Erden

Cumhuriyet sonrası Türk resim sanatında tören-bayrak ilişkisi örneklerine sıklıkla rastlanmaktadır. Törenlerin siyasal iktidarla ilişkisi çoğunlukla açık göstergelerle oluşturmaktadır. Avrupa, Fransız Devrimi ile başlayan tarihsel süreçte ulus devlet formuna yönelirken, imparatorluk dönemlerinden hatta daha eski dönemlerden kalma, ayin-tören ilişkisinden uzaklaşmıştır. Sibel Özbudun'a göre: "Ulusal bayrak, marş, ulusal önderler, ulusal mitoloji ve tabii ki törenler, bu sivil ve seküler dinin araçlarıdır" (Özbudun, 1997: 130). Bu açıklamalar bağlamında ulus devlet inşasında törenlerin, devletin halka buluştuğu ya da devletin varlığını net bir şekilde görülmesini sağlayan önemli olgulardan biri olduğu söylenebilir. Türkiye'de de cumhuriyet rejimine geçişle birlikte törenler önemli bir unsur haline gelmiştir. Bu etki resim sanatında da hissedilmektedir. Türk resmindeki tören-bayrak ilişkisinde toplumun bir yansıması görülmekle birlikte, siyasal amaçları da 
görülmektedir. Buresimlerdebayrakgenellikleideolojikolanınsimgesiolarak bulunmaktadır. Diğer bir deyişle, ideoloji açık bir dille ifade edilmektedir. Oysa Cihat Burak'ın çalışmasında tören, tam da burada bahsedilenin dışında durmaktadır. Örneğin Mehmet Ruhi Arel'in 1931 yılında üretmiş olduğu "Resmi Geçit" adlı çalışmasında, tören daha çok militarist imgelerle ilişkilendirilirken, Cihat Burak'ın çalışmasında doğrudan devletin varlığını hissetmekten çok; halkın bu durumu nasıl içselleştirdiğini, şenlik ve kutlama etkisini daha çok vurguladığı görülmektedir. Bu çalışmada da bayrağın, halk tarafından coşkuyla benimsenen vatanı simgelediği açıktır. Elbette ki bayrak varlığı gereği siyasal bir nesnedir. Fakat anı yakalamak ve aktarmak söz konusu olduğunda, bayrak bulunduğu mekânın parçası olarak plastik bir unsur haline gelebilmektedir. Burak'ın çalışmasında da siyasal nesnenin belgesel nitelikli etkisini, sanatçının kendi üslubu ile izleyiciye aktardığını görmek mümkündür.

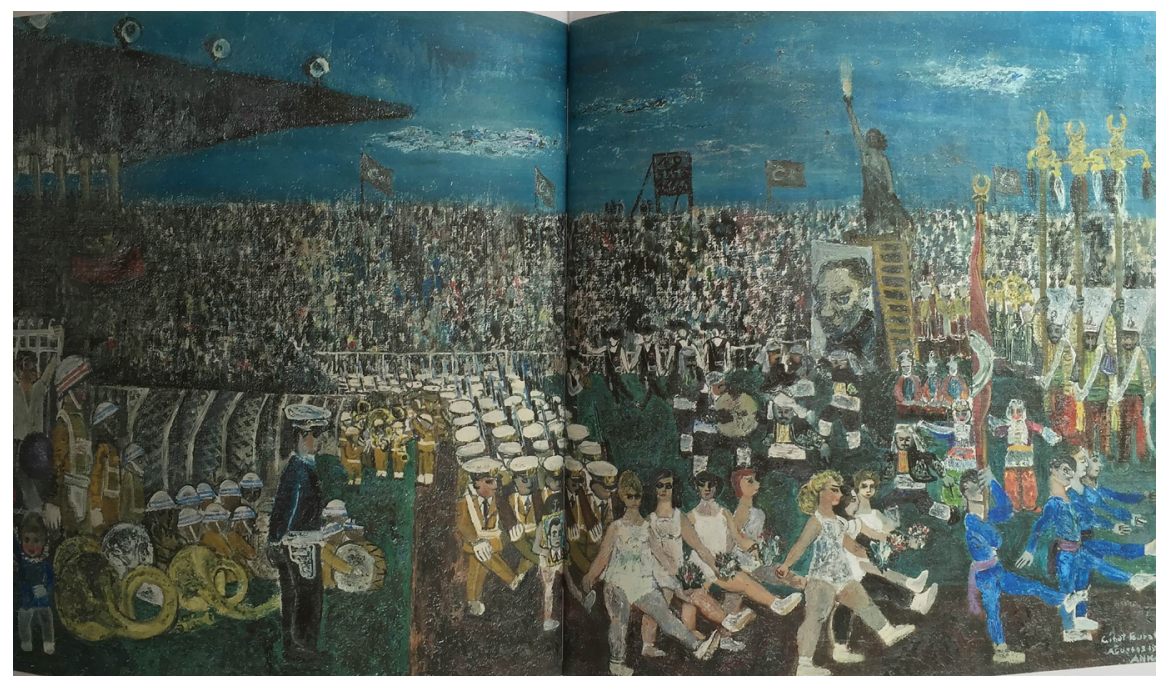

Resim 3. Cihat Burak, 19 Mayıs 1960, 1960, T.Ü.Y.B., $95 \times 175 \mathrm{~cm}$. 


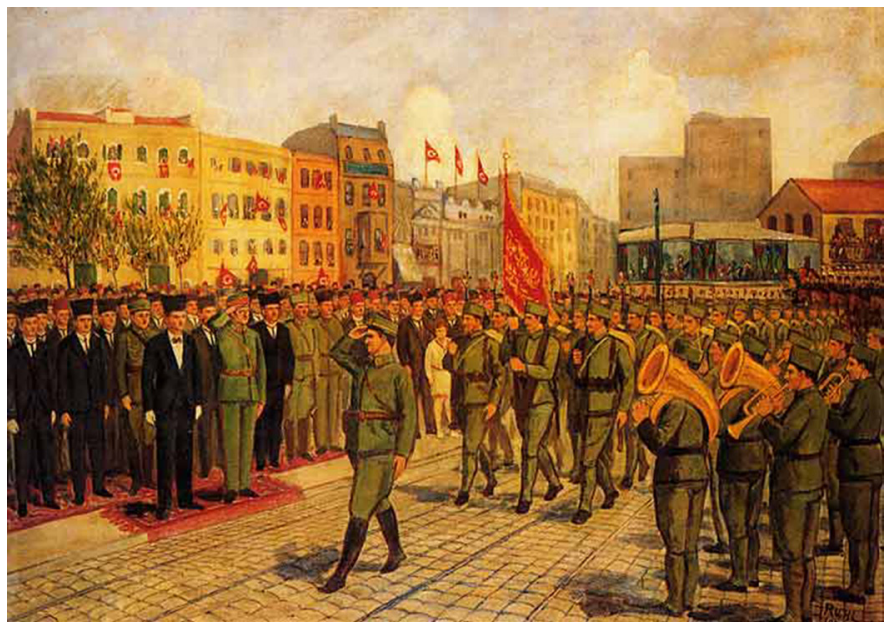

Resim 4. Mehmet Ruhi Arel, Resmi Geçit, I93I, T.Ü.Y.B., I47xIII cm.

Resmi kurumlara ait binalara asılan bayraklar dışında gündelik yaşamın içinde bayraklar sıklıkla kullanılmaktadır. Michael Billig'e göre: "sallanan bayraklar ve sallanmayan bayraklar" vardır ve Billig bu bayrakları "banal milliyetçilik" olarak sınıflandırmaktadır. Dalgalanmayan bayraklar aracılığı ile "Millet her gün rutin olarak kendisini kutlamaktadır" (Billig, 2002: 63). Yazarın bahsettiği madeni paralar üzerindeki bayraklar, futbol maçlarında kullanılan bayraklar banal milliyetçiliğin uzantısı olarak kullanılan dalgalanmayan bayraklara örnektir. Türk toplumunda ise yazarın bahsettiği türden sallanmayan bayrakların sıklıkla kullanıldığı görülmektedir. Örneğin, inşaatlara asılan bayraklar, düğünlerde kullanılan bayraklar, kişisel otomobillere asılan ya da yapıştırılan bayraklar, ay-yıldızı fincanlar, takılar, seyyar satııların tezgâhlarına astıkları bayraklar gibi birçok örnek verilebilir.
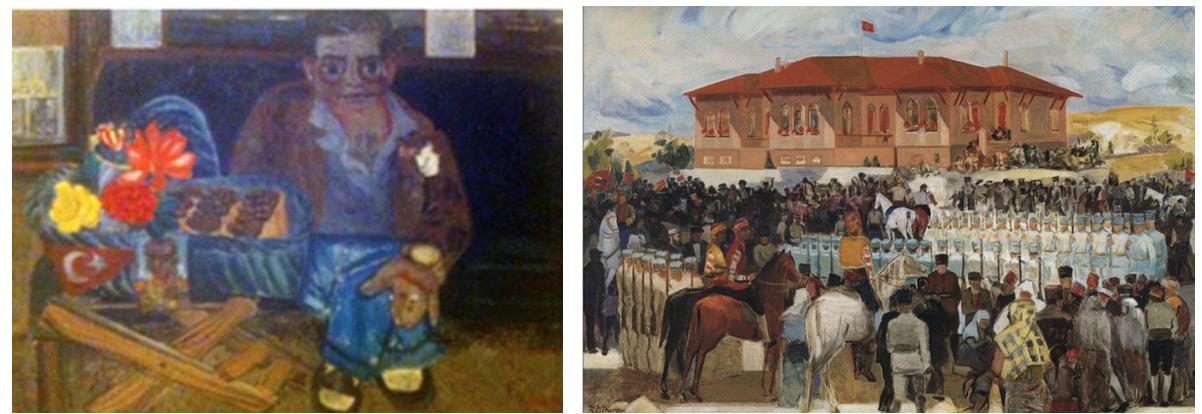

Resim 5. Cihat Burak, Fıstıkçı Ibrahim, 1968, T.Ü.Y.B., 60x8I cm.

Resim 6. Refik Epikman, Ilk Meclis, 1960, T.Ü.Y.B., $100 \times 141 \mathrm{~cm}$. 
Cihat Burak'ın "Fıstıkçı İbrahim" (1968) adlı çalışmasında da bu yönde örnek verilebilecek bayrak imgesi bulunmaktadır. Seyyar fıstıkçı tezgâhının üzerinde bir ay-yıldız göze çarpmaktadır. Burak, Billig'in bahsettiği milliyetçilik uzantısını aktarma amacında olduğu söylemek doğru bir yaklaşım olmayacaktır. Cihat Burak'ın eseri ile içeriğinde nesne üzerinde bayrak olması bağlamında Şeref Akdik'in "Okula Kayıt" çalışmasıyla karşılaştırıldığında, Akdik'in çalışmasını, dönemin okuma yazma seferberliği üzerinden, ulus bilinci ve milliyetçilik kavramları bağlamında göstergeler taşıdığını söyleyebiliriz. Bu açıdan bakıldığında da tüm Batı sanat tarihinde nesneler aracılığı ile izleyiciye mesaj aktarma amacı akıllara gelmektedir. Örneğin, "Hollanda resminde dini konuların resimlenmesine ilişkin yasak, dini ve ahlaki konuların günlük yaşam üzerinden ve sıradan nesneler vasıtasıyla işlenmesini beraberinde getirmiştir. Post-ikonoklast tavırla ilahi konu sıradan nesnelerin bağlamını kurmuştur. Doğrudan ifade edilemeyen, burjuva beğenisi ve yaşamını yansıtan nesneler aracılığıyla dile getirilmiştir" (Bozturgut, 2013: 65). Akdik'in çalışması bu bağlamda ele alındığında, devlet memurunun elindeki nüfus kâğıdının üzerindeki ay-yıldız imgesi izleyiciye mesaj iletmeye kaygısı barındırmaktadır. Oysa Burak'ın çalışmasında bu yönde göstergeler yoktur. Daha önce de değinildiği gibi, sanatçının belgeleme ve bunu kendi üslubuyla yorumladığını söylenebilir. Resmin konusu olan Fıstıkçı ibrahim'in iç dünyası, zor şartlarda hayata tutunması ve ülkesine olan bağlılığı, Burak'ın ilgilendiği asıl konu olduğu söylenebilir. Ayrıca, halkın estetik algısına dair de bir belge niteliğindedir. Yine buna benzer bir bayrak imgesi sanatçının "Zabit Ailesi" (1991) adlı çalışmasında da görmek mümkündür. Sanatçının kendi aile fotoğrafından yararlandığı resimde, arka planda ay-yıldız imgesi görülmektedir. Buradaki bayrak doğrudan milliyetçilik bağlamında okunulamayacağı gibi, sanatçının fotoğraf referanslı çalışmasıyla ve dönemin fotoğraf çekimlerinde bayrak imgesinin kullanılmasıyla ilişkilendirilebilir. Sanatçının "Salacak, Arab'ın Yerinden Kız Kulesi" (1992) adlı çalışmasında da, Kız Kulesi üzerinde asılı bayrak imgesi bulunmaktadır. Billig'in doğrudan milliyetçilik üzerinden ilişkilendirilebilecek bayrak açıklamasına uygundur ama sanatçının bu amaca hizmet ettiğini söyleyecek göstergeler bulunmamaktadır. Cumhuriyet dönemi ideolojisine göndermeli mimari-bayrak ilişkisi olan çalışmalarda Billig'in bahsettiği yönde eserlerle karşılaşılmaktadır. Örneğin Refik Epikman'ın "ilk Meclis" (1960) adlı çalışması bu yönde örnek verilebilecek çalışmadır. Çalışmada bayrak hem kompozisyonda en üst noktada durmakta hem de devletin merkezi olan meclis binası bu ilişkiyi kuvvetlendirmektedir. Cihat Burak'ın çalışmasında ise bayrak, görülen manzaranın bir parçası olarak, haritada bir konumu belirleyen araç olarak kullanılmıştır. 

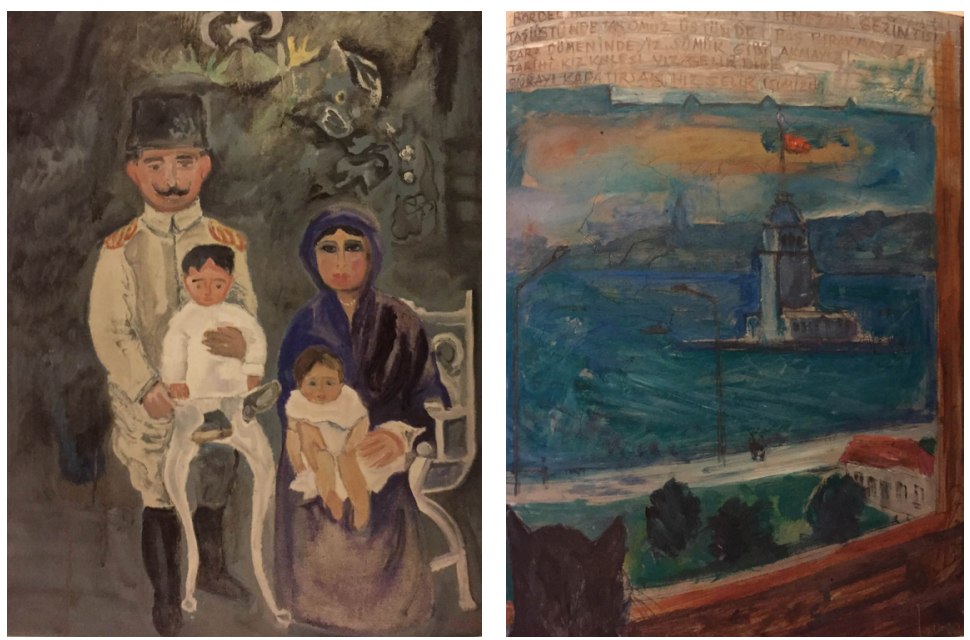

Resim 7. Cihat Burak, Zabit Ailesi, I99I, T.Ü.Y.B. $88.5 \times 68 \mathrm{~cm}$.

Resim 8. Cihat Burak, Arab'in Yerinden Kızkulesi, 1992, D.Ü.Y.B., $39 \times 30 \mathrm{~cm}$.

“Batı'da toplumsal ve siyasal konuların ağırlıklı olduğu 1960'lar sonrası sanat hareketleri, bir durum karşısında tavır alan, gündelik gerçeklikle, toplumla ilişki kuran, sosyal siyasal, kültürel olgularla yoğun biçimde uğraşan çağdaş sanat, Türkiye'de seksenli yıllarda yaygınlaştı" (Duben, 2008: 24). Duben'in açıklamaları ışığında, Cihat Burak'ın resimlerinde bayrağın siyasal olarak kullanımı ve bu bağlamda politika-sanat ilişkisinin kurulabileceği eserleri arasında en belirgin "Şairin Ölümü" ve "Sultan Sofrası" adlı çalışmalarında görülmektedir. Sanatçının konular üzerindeki hassasiyeti bu çalışmalarda açıkça göstergeler üzerinden okunabilmektedir. Burak'ın 1967 yılında üretmiş olduğu "Şairin Ölümü" adlı eserinde Nazım Hikmet portresi inşa etmektedir. Daha önce de değinildiği gibi gazete fotoğraflarından yararlanan sanatçının eserinde, bu fotoğraflar aracılığı ile resmin alt metnini okumak mümkündür. Triptiğin sol parçasında Nazım Hikmet'in Bursa Cezaevi'ndeki kedili fotoğrafından, resmin sağ triptiğinde ise arkadaşı Vala Nureddin ile birlikte oldukları bir fotoğraftan, yine o dönemin siyasi tutuklusu Şadi Alkılıç'ın fotoğrafından yararlandığı görülmektedir. Resmin içindeki figürler, 1960'lı yılların siyasi bir yansımasıdır. Triptiğin sağ parçasında, öndeki mavili figürün göğsünde Türk bayrağı açıkça görülmektedir. Arka planda, 1960'lı yıllardaki öğrenci hareketlerinde kullanılan "Coca Cola Go Home" pankartı taşıyan figürler aynı zamanda bir Türk bayrağı taşımaktadır. Yine sağ parçada Alkılıç'ın yanında polislerin önünde bayrak imgesi bulunmaktadır. Bayrak imgesi dönemin siyasi sürecinin aktarılmasına yardımcı olan bir gösterge olarak kullanılmış ve yine bir belge niteliği barındırmaktadır. Vatan haini ilan edilen 
Nazım Hikmet'in hem siyasal figürlerle hem de bayraklarla birlikteliği, vatanseverlik kavramını sorgulamamıza yardımcı araç olarak kullanıldığını söylemek mümkündür.

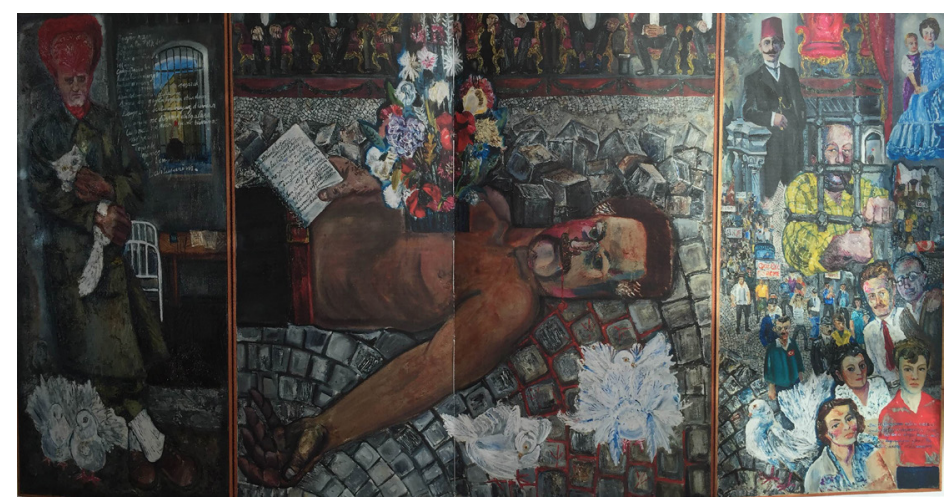

Resim 9. Cihat Burak, Şairin Ölümü, 1967, T.Ü.Y.B., $127 \times 200$ cm.
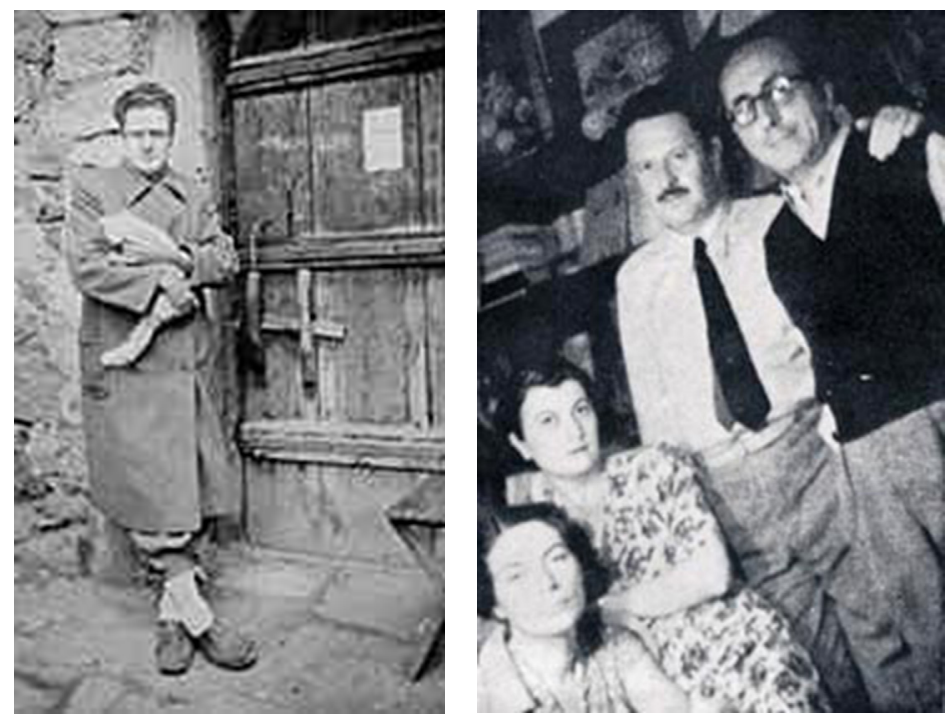

Resim 10. Nazım Hikmet

Resim II. Nazım Hikmet ve Vala Nureddin

"Sultan Sofrası" (1984) adlı çalışmada, resimdeki göstergelerden de anlaşılacağı üzere 1980'li yılların Türkiye'sinin ekonomi alanındaki atılımlarını ve dönemin popüler siyasal kimliklerini resimsel kurgu aracılığı ile görmek mümkündür. Askeri darbe sonrası Turgut Özal'lı günlerin başlaması ve bu bağlamda liberalleşen Türkiye'nin bir fotoğrafı gibidir. 
Resim dikey kompozisyonda oluşturulmuş ve üç bölüme ayrılmıştır. Resmin orta kısmında Turgut Özal ve kostümlerinden anlaşılacağı gibi Arap konuklar, çokça seçeneğe sahip Türk mutfağına ait yemekler ve tatılırın arasında durmaktadır. Üst bölümde, tüm olan biteni izleyen gecekondu sakinleri bulunmaktadır. Arka plandaki cami minarelerine asılı mahyada ise "Saraydan Kız Kaçırma Operet 3 Perde" yazmaktadır. Bu açıdan bakıldığında, gecekondu sakinleri ve operet arasındaki sınıfsal çelişkinin karmaşası, aslında Özal'a yönelik bir eleştiri gibidir ve halk olan biteni izlerken, Burak ironik yaklaşımı ile durumu özetlemektedir: "Saraydan Kız Kaçırılmaktadır". Bu açıdan bakıldığında, Turgut Özal'ın başbakanlık döneminde liberalleşme politikalarıly eleştirilmesinin bir yansıması resimde görülmektedir. Resmin alt bölümünde ise bankta yaşlı bir çift oturmaktadır ve Cihat Burak'ın resimlerinde sıklıkla karşımıza çıkan kediler vardır.

Dönemin bankalarının reklam aracı olarak kullandığı ve belediyeler aracılığı ile birçok parkta bulunan bankanın isminin yazdığı eşantiyon bankların bir örneğidir. Bankta "Orta Direk Bankası" yazmaktadır. Sanatçının resim yüzeyinde kullandığı bütün nesneler, bir sembol olarak döneme ait notlar barındırmaktadır. Gerek kapitalizm eleştirisi olarak bank göndermesi, gerekse gecekondu aralarından bakan figürler ya da bankta "simit, peynir, zeytin" yiyen yaşı çiftin bulunduğu sınıfa ait semboller, nesneler aracılığı ile izleyiciye aktartılmaktadır. Bankta oturan kadın figür, şiş ve iplerle bir Türk bayrağı örmektedir. Kullanılan bayrak ve örme metaforu, yeni Türkiye'de kapitalizmle birlikte oluşan gelir farklarını, sınıfları, iktidara düşen payı ve yeni Türkiye'nin sessizce olanları izleyişine dair göndermeler barındırmaktadır (Çalışkan, 2016:103).

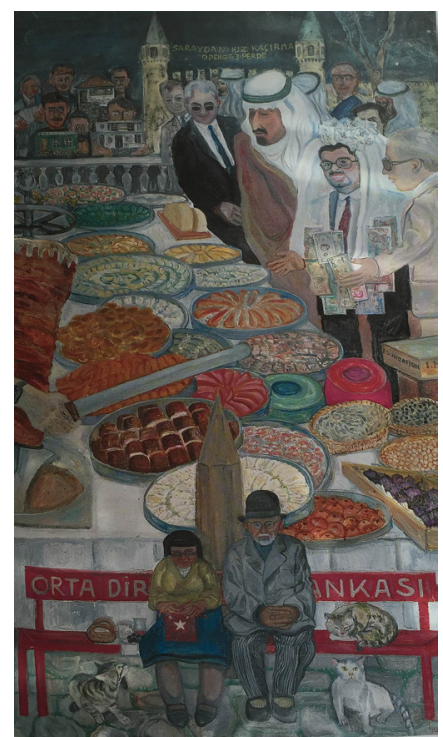

Resim 12. Cihat Burak, Sultan Sofrası, 1984, T.Ü.Y.B., I60x86 cm. 
Osmanlı İmparatorluğu'ndan günümüze, ilaç kutularından tütün tabakalarına, yemek takımlarından halılara madeni ve kâğıt paralardan pullara gibi çoğaltılabilecek çok geniş bir alandaki günlük kullanım nesneleri üzerinde bayrak imgesi bulunmaktadır. Bazen süsleme ögesi olarak bazen de popüler milliyetçiliğin uzantısı olarak karşımıza çıkan bayrak imgesi, Türk resim sanatında da hemen hemen her dönemde farklı bağlamlarda ele alınmıştır. Cihat Burak'ın çalışmalarını sanatçının yaşadığı dönemi de göze alarak okumakta fayda vardır. Sanatçı Türk siyasal tarihin en karışık dönemlerine tanıklık etmiş, birkaç askeri darbeyi yaşamıştır. Bu açıdan bakıldığında da Burak'ın, bayrak imgesinin varlık olarak taşıdığı hassas anlamlarını ele alırken kullandığı üslup ilgi çekicidir.

\section{Sonuç}

Bayraklar her ne kadar sıradan bir nesne olsa da, siyasal anlamda birçok bağlamda varlık göstermektedir. Sanatçıların da bu simgesel nesneyi, konularına göre farklı bağlamlarla incelediği açıktır. Bayrak imgesinin yoğun bir şekilde kullanıldığı Türk resim sanatında, Cihat Burak'ın üslup ve içerik olarak bayrak imgesini farklı bir gözle incelediği açıktır. Farklılık ile kasıt, Cihat Burak'ın alışılmış olanın dışında yorumlar eklediğine vurgudur. Kurtuluş Savaşı ile ilgili büyük anlatılara karşın Burak'ın bambaşka bir noktadan ele aldığı Kara Fatma adlı çalışmasında Anadolu insanını, kadın imajını kendi üslubuyla resmetmiştir. Yine Cumhuriyet dönemi eserlerinin aksine, sanatçının naif bir dille ele aldığı tören-bayrak ilişkisi, mimaribayrak ilişkisi ve nesneler üzerindeki bayrakları sanatçının ele aldığı figürlerle yarattığı atmosferin farklılı̆ı dikkat çekici olduğu açıktır. Siyasal olanla ilişkisi bağlamında Şairin Ölümü ve Sultan Sofrası adlı çalışma, 1990 sonrası akademik resimden uzaklaşan ve farklı arayışlara yönelen Türk resim sanatına etkileri, politika sanat ilişkisi bağlamında öncül bir noktada durduğu bellidir. Makalenin araştırma sürecinde ulaşılan bilgiler ışı̆̆ında, Cihat Burak'ın fotoğrafla kurduğu ilişki ve bunu sanatına aktarması başka bir çalışmasının konusunu oluşturacak derecede önemlidir. 


\section{Kaynakça}

Barthes, R. (20I2). Göstergebilimsel Serüven, (çev. M. Rifat, S. Rifat) Istanbul: Yapı Kredi Yayınları.

Billig, M. (2002). Banal Milliyetçilik, (çev. C. Şişkolar), İstanbul: Gelenek Yayıncılık.

Bozturgut, A.Ö. (2013). "Flaman resmi Bağlamında Gerçekliğin Post-ikonografik Resmi Olarak Fotografik görüntü”, Kocaeli Üniversitesi Sosyal Bilimler Dergisi, 25 (I), 65-7I.

Çalıkoğlu, L. (2008). Cihat Burak Retrospektifi, İstanbul: İstanbul Modern Sanat Müzesi Yayınları.

Çalışkan, S. (20I6). Türk Resim Sanatında Türk Bayrağı Imgesi, Yayımlanmamış Sanatta Yeterlik Tezi, Marmara Üniversitesi Güzel Sanatlar Enstitüsü, İstanbul.

Duben, I., Yıldız, E. (2008). Seksenlerde Türkiye'de Çă̆daş Sanat: Yeni Açılımlar, İstanbul: İstanbul Bilgi Üniversitesi Yayınları.

Durkheim, E. (20I I). Dini Hayatın Illkel Biçimleri, (çev. F. Aydın) Ankara: Eski Yeni Yayınevi. Kurtoğlu, F. (1987). Türk Bayră̆ı Ve Ay Yıldız, Ankara: T.C. Kültür ve Turizm Bakanlığı Yayınları.

Ögel, B. (1984). Türk Kültür Tarihine Giriş VI, Ankara: T.C. Kültür ve Turizm Bakanlığı Yayınları.

Öndin, N. (2003). Cumhuriyetin Kültür Politikası ve Sanat 1923-1950, İstanbul: Insancıl Yayınları.

Özbudun, S. (1997). Ayinden Törene, İstanbul: Anahtar Kitaplar Yayınevi.

\section{Görsel Kaynaklar}

Resim I, 3, 7, 8, 9, I2. Çalıkoğlu, L. (2008). Cihat Burak Retrospektifi, İstanbul: Istanbul Modern Sanat Müzesi Yayınları

Resim 2. http://tarihturko.tr.gg/FATMA-SEHER--kI-KARA-FATMA-k2-.htm(I0.0I.20I6)

Resim 4. Şişli İnkılap Müzesi Koleksiyonu - http://www.tarihnotlari.com/ruhi-arel/

Resim 5.Koçak, O. (2009).Modern ve Ötesi Elli Yılın Kenar Notları, İstanbul: İstanbul Bilgi Üniversitesi Yayınları.

Resim 6. T.C. Kültür ve Turizm Bakanlığı Ankara Devlet Resim Heykel Müzesi Koleksiyonu 
Resim 10. http://www.turkcebilgi.com/nazım_hikmet (15.0I.2016)

Resim II. http://mehmetbilgehanmerki.blogspot.com.tr/20/4/05/salkim-sogutun-yazilishikayesi.html(10.01.2016) 